\title{
AT HOME IN SHENZHEN? HOUSING OPPORTUNITIES AND HOUSING PREFERENCES OF CREATIVE WORKERS IN A WANNABE CREATIVE CITY
}

\author{
Marco BONTJE \\ University of Amsterdam, \\ Faculty of Social and Behavioural Sciences, \\ Department of Human Geography, Planning and International Development Studies \\ Spui 21, 1012 WX Amsterdam, The Netherlands \\ E-mail: m.a.bontje@uva.nl
}

Received 27 October 2015; accepted 12 June 2016

\begin{abstract}
Shenzhen grew fast as a city of industrial mass-production, but is transforming to an innovative and creative city. Shenzhen's policies to encourage the creative industries are mostly aimed at companies and entrepreneurs. To really become an attractive creative city, housing policies for creative talent should be added. This article reports on an interview-based analysis of the housing situation and residential preferences of creative workers in Shenzhen. While creatives with good salaries have no problems finding attractive homes and neighbourhoods in Shenzhen, there is a shortage of affordable neighbourhoods meeting the demands of recent graduates and starting creatives. Shenzhen's creative city strategy should take the socio-economic diversity of creative workers into account.
\end{abstract}

Keywords: China, creative city, creative workers, housing, residential preferences, Shenzhen.

\section{Introduction}

In the early 21st century, the "creative city" has become one of the most popular urban development strategies. Many Chinese cities, including Shenzhen, have also developed strategies to become creative cities. Shenzhen's extremely fast growth since the early 1980s initially was based mainly on industrial mass-production and cheap labour. Meanwhile its development focus has shifted towards high-tech production, innovation and creativity. This was partly a deliberate choice as a logical next stage in the city's economic development, which also fits well in the national Chinese ambition to move its economy "from made in China to designed and created in China". Partly also, however, this strategy shift was forced by protests of the labour force, rising salaries as a result of this, rising land an real estate costs, and factories leaving the city in response to these rising costs. Creative industries are seen as one of the key sectors in this economic transformation. The city has taken several initiatives 
to stimulate the development of creative industries and to attract and educate creative talent. Shenzhen's creative city strategy includes the successful application as one of UNESCO's "Cities of Design"; events like an architecture biennale, a China (Shenzhen) International Cultural Industries Fair, and the yearly Creative December programme; designating business sites as "creative parks"; and funding for start-up companies (Costa 2013; Bontje 2014).

The policy measures taken so far are mostly aimed at companies and workplaces, much less at improving the city as a place to live. However, to really become an attractive city for creative business, entrepreneurs and workers, creating attractive work locations alone is not enough. According to influential authors on creative cities like Richard Florida (2002), creative city strategies should be about "work", "live" and "play".

This article mainly focuses on the "live" dimension of the creative city, asking to what extent Shenzhen is not only an attractive city for creative businesses, but also for creative workers. The article results from a qualitative analysis based on 35 interviews with people working in Shenzhen's creative industries. The respondents were asked about their current residential situation, to what extent they were satisfied with it, their residential preferences and their ideal living environment (more details about the methodology in the section "Research strategy and respondents"). So far, Shenzhen's housing policy does not seem to be linked well to its economic development policy and its strive to become a more creative city. Creative workers are a highly diverse group of people with quite different needs and preferences about their home and living environment. They are definitely not all belonging to the middle or upper class. Especially those at the start of their career are not rich at all and have trouble finding an affordable place to live. Large parts of Shenzhen's private housing market are not affordable for them. Unfortunately, the public housing sector is no alternative for them either: so far it is a very small segment of the Shenzhen housing market, and it is not accessible for those lacking a local urban hukou residential permit. Not all creative workers possess this local urban hukou. They are "falling in-between": not rich enough for the private market, not eligible for public housing. Many of them therefore have to settle for far from ideal alternatives, like flat sharing or renting small low-quality apartments in "urban villages".

The housing needs and preferences of creative workers have not been researched much in China yet, but international theories and research results from other parts of the world may give some ideas of what to expect in the Chinese context. In the next section we will briefly review this literature. We will then turn to the case of Shenzhen: what types of housing and living environments can be found in this city and to what extent could these be attractive for creative workers? This provides the context for the interview-based analysis presented in the rest of this article.

\section{Where creatives (like to) live: theory and evidence from the Western world}

So far there is hardly any research about housing preferences of people working in the creative industries in China. There is already a Chinese creative city debate, but this is mainly about creative clusters and the role of creative industries in China's economic 
and societal modernization (Keane 2011; Wuwei 2011; O'Connor, Xin 2006; Costa 2013). In recent international literature, scarce examples of links between China's housing policies and creative city/knowledge city strategies include Nicola Morrison (2014) about Shenzhen's first attempts to create talented worker housing policies, and Julie Tian Miao (2016) on the links between science park development and housing provision for knowledge migrants in Beijing, Shanghai and Wuhan. There is much more research about housing preferences of creative workers in advanced capitalist countries. Although these parts of the world differ from China in many respects, still we may find some clues about what to expect for Chinese cities.

Florida's "creative class" hypothesis implies that attracting creative talent is the key to urban economic growth in the early 21 st century (2002). He suggests that a new class has emerged, including about one-third of the working population, working in creative and knowledge-intensive industries. This creative class would have specific preferences for where and how to live: they would especially like highly urban environments, preferably in or close to the city center, mixed-use lively neighbourhoods with a rich offer of "street-level culture". His attraction factors for the creative class also include hard-to-grasp concepts like "authentic places" and "quality of place". The argument that drew most attention, though, is Florida's plea for tolerance and diversity as key attraction factors for creative talent. This includes tolerance for and diversity of people from different ethnic and cultural backgrounds, with different lifestyles and/ or different sexual orientations. Several other North American researchers had comparable arguments, like Richard Lloyd (2002) reporting on the rise of "neo-bohemia", and Terry Nichols Clark, Lloyd, Kenneth K. Wong, Pushpam Jain (2002) claiming that urban economic growth was mainly driven by urban amenities.

Florida's creative class hypothesis sparked a lively debate. Next to criticisms on Florida based on counter-evidence or on doubts about Florida's own data (e.g. Glaeser 2004; Malanga 2004; Hansen, Niedomysl 2009; Musterd, Gritsai 2013), many authors also attacked his theoretical assumptions and/or the possible policy implications of his approach to urban economic growth (e.g. Peck 2005; Scott 2006; Pratt 2008; Bontje et al. 2011). Researchers from non-American contexts criticized the "North American bias" in Florida's theory and the evidence it was based on. The European project "Accommodating Creative Knowledge", for example, included a survey in which workers in creative and knowledge-intensive industries were asked about where they lived, why they lived there and how satisfied they were about their home and living environment. Instead of the "soft factors" that Florida emphasizes (see above) and the "classic" or "hard" location factors like labour market, housing affordability, infrastructure and distance to the workplace, a third category of factors appeared most important in almost all 13 city-regions analysed: personal life trajectories and networks. This third category included where the respondents were born and grew up, where they studied, and where their family and friends lived. This seems to imply that workers in creative and knowledge-intensive industries (at least in Europe) may be less "special" than academics like Florida suggest. However, when trying to explain reasons for people to stay put (whether or not they planned to move and which would be reasons to move or not), Florida's soft factors appeared to become more important 
(Martin-Brelot et al. 2010; Musterd, Gritsai 2013). Other European research projects arrived at comparable conclusions. Høgni Kalsø Hansen and Thomas Niedomysl (2009: 191), for example, state that creative class migrants in Sweden "move for jobs rather than place" and that the location of the university where they studied plays an important role in their migration behaviour.

Another international academic debate with relevance for this article's research topic is about gentrification. The categories of "creatives" and "gentrifiers" show considerable overlap; however, not all creatives are gentrifiers, and not all gentrifiers are creative. Gentrification is a very broad and multifaceted concept and academic and societal debates about it are often confusing. Gentrification may come in lots of shapes and sizes, which may also include "Chinese variations" (Song, Wu 2010). Still, in the advanced capitalist cities where most gentrification research has been done, the same types of urban environments and actors and the same process come to the fore (see e.g. Ley 1996; Carpenter, Lees 1995). The "market-driven version" often starts with a deprived area built in the late 19th or early 20th century. "Pioneers" like artists, students or squatters refurbish vacant buildings and create their own neighbourhood infrastructure of shops, restaurants, workspaces etc. This attracts visitors and later also middle-class residents. In a next stage investors and higher-class people move in and the former working class area becomes a bourgeois neighbourhood. There is also a "state-led" version of gentrification where gentrification may be the (intended or unintended) result of an urban regeneration programme. Both the "pioneer" and the "middle class" categories of gentrifiers usually include people with creative professions and/or those aspiring to become creative professionals.

\section{Do creative class and creative city theories apply to Chinese cities?}

Chinese cities, housing markets, creative industries and creative workers differ in many respects from the advanced capitalist contexts where most creative cities literature so far comes from. First, in most Chinese cities, after decades of radical transformation, there are few places left that could gentrify. In cities with a long trading history like Shanghai, Beijing or Guangzhou, there were still remnants of earlier phases of industrial, trade or harbour activities with gentrification potential. Some of the former factories of the 1970s and 1980s have also been redeveloped into creative environments. However, so far these have mainly become creative workspaces, not living spaces. Chinese urban renewal most often is demolition and new construction instead of refurbishing and reconstruction. The potential value of cultural heritage has only recently become more prioritized in Chinese urban (re)development strategies; for many old neighbourhoods this recognition came much too late. Still, some Chinese researchers claim that gentrification is part of Chinese urban transformation, albeit probably in a form that is hard to compare to Western cities (Song, Wu 2010; He 2010).

Second, high-rise complexes dominate Chinese cities and most of their citizens are used to living in them. Most Chinese may not consider smaller-scale urban or nonurban living environments as possibly attractive alternatives, and may have less appreciation for historic inner cities than Europeans. A comparable Chinese-European 
contrast is the rapidly increasing share of gated communities and other forms of "urban enclaves" in Chinese cities. "Enclave urbanism" (Douglass et al. 2012) is not exclusively an elite phenomenon; there are also an increasing number of middle-class enclaves. Still, focusing on our specific labour market category of people working in creative industries, such urban enclaves are probably only affordable for senior staff and successful entrepreneurs, and not for starting creatives or junior staff.

Third, especially in China's largest cities, "urban villages" offer a huge challenge for policy-makers and developers involved in urban (re)development strategies. "Urban villages" can hardly be compared to any part of present-day European or North American cities. Most of the urban villages are former rural communities, becoming the main destination for migrant workers after the villages became part of the fast expanding cities. Recently, though, the urban village population is changing, especially in those urban villages in relatively central and accessible locations. The urban village seems to become an increasingly important housing alternative for creative workers with lower incomes and/or at the start of their labour and housing career. This is not only related to new types of residents moving to the urban villages from other parts of the city, but also to changes in the migrant population itself in terms of skills, education, ambitions and expectations (Cheng 2014; Wu, Gaubatz 2013; Wang, Fan 2012).

Finally, looking at Florida's creative class attraction factors, tolerance and diversity are problematic factors in China. China is not yet a very welcoming society for international migrants, and lifestyles and preferences diverging from the mainstream are generally not as accepted as in Western societies. Florida, Charlotta Mellander and Haifeng Qian (2012) found that just like in Western societies, China's most talented people tend to move to city-regions that are more tolerant and open and have a more diverse population. They recommended Chinese authorities to recognize the importance of these factors more. However, they also found that so far, the relationship between concentrations of the creative class, innovation and regional economic performance were quite weak. This is probably related to the early phase of economic transformation China is still in; the transformation from an industrial economy to a creative-knowledge economy is still far from completed.

\section{Shenzhen's residential landscape: attractive for creatives?}

For Shenzhen it may be even more difficult to become an attractive residence for creatives than for older Chinese cities. Shenzhen has a unique urban development history which is hardly comparable to any other Chinese city. Shenzhen's spectacular growth story did not start "from scratch": there were small towns, villages and scattered farms before large-scale industrial and urban development began (Cartier 2002; Ng 2003; Zacharias, Tang 2010). The city does have some cultural heritage (Liu, Ng 2009), but still, most of Shenzhen has been built since the early 1980s. Cities with a longer urban history and more cultural heritage have the types of buildings and areas where gentrification usually takes place. Shenzhen hardly has such places, so it tries to create them or to redevelop more recent industrial heritage. Places like OCT-LOFT or F538 are created in former factory complexes of the 1980s. Although these may not be the best 
suited environments to act as "magnets for creatives", the mix of functionalistic factory halls with newly added state of the art architecture and an attractive public space design seems to work. These places, however, so far are mainly creative workspaces, not living spaces.

Especially in its first years, Shenzhen was designed to serve the fast growth of industrial mass production. An attractive living environment only became a policy priority much more recently. After decades of focusing on "production space", Shenzhen's 2011-2015 Five Year Plan is the first to develop "consumption space" policies, acknowledging challenges for urban competitiveness like housing affordability (Morrison 2014). Some parts of the city may already be attractive consumption spaces longer, though, like the Overseas Chinese Towns (OCT) in Nanshan and Dameisha (OCT East). However, whether such "Disneyfied" environments (copying for example Italian seaside towns, Swiss mountain resorts, or ancient Chinese villages) are attractive for creatives is questionable; moreover, the OCT developments are quite expensive places to live.

An additional obstacle is the highly fragmented city structure. Especially Shenzhen's central districts increasingly consist of walled, fenced or otherwise separated "urban enclaves", while public space and other integrating elements are relatively scarce compared to other Chinese cities. Maybe traffic infrastructure is all that keeps the pieces of Shenzhen together, and unfortunately these transport links are not only links but also barriers between the neighbourhoods. Enclave urbanism (Douglass et al. 2012) is not unique to Shenzhen, and it has a long tradition in China going back to walled cities, courtyard housing and more recently the danwei (He 2013). However, Shenzhen is a quite extreme case, and its fragmentation is increased even further because it has much more urban villages than any other city in China (Hao 2012). This has also contributed to a highly polarized society.

However, Shenzhen may also have advantages that could partly compensate the above mentioned disadvantages. Being "new" could offer opportunities that older cities may not have. Instead of trying to redevelop existing structures to make them more attractive for creatives, could Shenzhen not try to build something new and original that could be equally attractive or even more attractive for creatives? Justin O'Connor and Lie Liu (2014) suggest that this "newness" together with Shenzhen Special Economic Zone status contributed significantly to its emergence as a city of design. Another potentially rich resource is Shenzhen's highly diverse population. With a population largely consisting of first or second generation migrants, originating from all corners of China, Shenzhen may be a relatively tolerant place compared to other Chinese cities. If Shenzhen would manage to find a way to better integrate migrants into its urban society, this diverse population could be an attraction factor for creatives. However, we should keep in mind that Florida's hypothesis that creatives are especially attracted to diverse and tolerant places has met with considerable criticism; and as long as the hukou system remains an obstacle to migrant integration in the city, Shenzhen will remain a city in which migrants and non-migrants live highly segregated lives. 


\section{Research strategy and respondents}

In autumn 2012, 35 people working in Shenzhen's creative industries have been interviewed about their current housing situation, their housing preferences and their opinion about how the city of Shenzhen could become a more attractive place to live for them. The interviews were held in four creative parks in Shenzhen: OCT-LOFT, F518, Animation World and NH E-Cool. OCT-LOFT is a part of OCT in Nanshan District, Shenzhen; NH E-Cool and Animation World are both in Shekou, also in Nanshan District, Shenzhen; and F518 is in Bao'an District. OCT-LOFT is located quite centrally in Shenzhen, close to the Futian Central Business District, Shenzhen University campus and the high-tech industrial park of Nanshan. It is well connected by metro and highway to the rest of the city. The other 3 parks are in the west of the city: NH E-Cool and Animation World are close to Shenzhen's harbour; F518 is more distant from Shenzhen's main economic centres.

The interview sample definitely has selection biases. The other Shenzhen districts also have several creative parks, and probably there are also many creative workers and businesses outside of creative parks. The way we found and approached our respondents has added to this selection bias. We found several interviewees through the connections of architecture firm URBANUS in OCT-LOFT and the other creative parks; we asked respondents who else we could interview; and we mainly approached companies with easy access. OCT-LOFT clearly dominated in our interview sample: 19 interviews were with people working in OCT-LOFT, 6 in Animation World, 5 in F518, 3 in NH E-Cool, 1 in OCT outside the OCT-LOFT creative park, and 1 with a respondent without a fixed workplace. The results of our analysis should therefore definitely not be considered representative for Shenzhen as a whole.

The topics discussed in the interviews were:

- description of current home and neighbourhood;

- affordability of housing costs;

- satisfaction about current home and neighbourhood;

- "ideal home" and "ideal neighbourhood";

- what could the city of Shenzhen do to improve the residential situation of creative workers?

The respondents' age ranged from people in their mid-20s to people in their early 50s. Their household types were quite diverse too: singles, childless couples, couples with children, but also younger respondents still living in their parents' house. Our respondents were also representing quite different career phases and functions: interns, staff members, shop personnel, independent artists, entrepreneurs, self-employed, and chief executive officers of medium-sized companies. The respondents' diversity was increased further because they worked in four different creative parks with different specialization profiles. Nationality and ethnicity were less diverse: 30 "mainland Chinese" originating from different parts of China, 2 Italians, 1 German, 1 Australian, and 1 Taiwanese. Finally, we should add job diversity: 8 interior designers, 6 animation and graphic designers, 6 architects and architect interns, 6 people owning or working in galleries/creative products shops, 5 artists, a photographer, an architecture 
researcher, a clothes designer and an industrial designer. This makes it hard to formulate generalizing statements for the group as a whole, so what follows should be read with this variety in mind.

\section{Where the creatives are living now}

When describing their current living environment, only about two-thirds of our respondents referred to a specific location in the city. Some only referred to the district, some to a smaller-scale neighbourhood or to amenities like the nearest metro or bus station. Most respondents that did mention a geographic reference to their residential environment lived relatively close to their workplace. 10 respondents indicated that they were living in the Nanshan District, Shenzhen, where three of our four interview locations are situated. Not surprisingly, since we had most interviews in OCT-LOFT, 7 out of these 10 appeared to be living in the neighbourhoods around OCT. Maybe more surprising, since we did not have any interviews in that district, is that 6 of the respondents lived in Futian District. This included one respondent without a fixed work location; because of his function he frequently visited various companies spread across the city, so for him the city centre was a good home base. The other 5 were working in OCT-LOFT which is well connected by metro to Futian District. The other Shenzhen districts were less represented: 3 respondents lived in Bao'an District, close to their workplace in F518, 1 was living in Luohu District and 1 in Longgang District, Shenzhen. In fact, two of the three respondents living in Bao'an District were even living at their workplace: they lived and worked in one of the work-live cubicles built especially for artists in F518. Their workspace was on the ground floor, their bedroom on the first floor. Others did not mention a district or neighbourhood name; most of them even did not give any indication of where in the city their residence could be. However, this group also included 4 respondents saying they were living in an urban village (unfortunately not giving us the name). Probably this was a centrally located urban village since they also said they did not have to travel long to their workplace.

Almost all respondents gave quite detailed descriptions of the types of environments and buildings they were living in. The types of homes, all flats or apartments, could be grouped in the categories: renting an apartment or flat by themselves or with their partner and children; sharing an apartment or flat with other family members; or sharing an apartment or flat with friends, fellow students or others to make rent more affordable. Flat sharing is especially common among those with lower incomes at the start of their careers, while for those in a more advanced career stage with a higher income, having more than one home is quite common. Sometimes these homes are all within the city of Shenzhen; but more often, it is a combination of a Shenzhen home with a home in the city or village of origin, or the city or village where other family members live. The size and number of rooms varied from small one-room apartments of about $20 \mathrm{~m}^{2}$ (e.g. in urban villages or at Shenzhen University Campus) to large multiple-room apartments of more than $100 \mathrm{~m}^{2}$ in modern high-rise complexes. Most of the respondents lived in high-rise or medium-rise buildings, with heights typically ranging between 20 and 35 floors. These buildings most often were part of residential 
complexes consisting of several flats. Most of these complexes were close to amenities like public transport, shops, schools, restaurants and other public buildings. Several respondents indicated that it was either a fenced-off area or a "residential garden", the types of environments that the "urban enclave" literature refers to. The exceptions to this common pattern of "residential complex living" were respondents indicating they were living in urban villages, as well as respondents living at Shenzhen University Campus. The university campus offers less shopping, eating and nightlife amenities than most other centrally located residential environments; and urban villages are in an extremely dense, lively and functionally mixed league of their own.

\section{Housing affordability}

The diverse characteristics of respondents result in equally diverse housing careers and opportunities. A clear division could be made between those more advanced in their labour market career and those at the very start of their career. Only respondents already working in Shenzhen's creative industries for several years and with decent incomes managed to find their way on the Shenzhen housing market easily. For higher income groups, Shenzhen has many attractive apartments available. However, for lower and middle income groups, it is very hard to find an affordable home that meets their housing needs and preferences. An unfortunate combination of two problematic factors applied to many of the interview respondents: a too low salary to afford an apartment on the commercial market, and not being eligible for affordable public housing. The latter applies to two categories that both were well represented among the interview respondents: people earning too much for public housing (but too little to afford commercial market rents), and people with a low enough income to be eligible for public housing, but lacking the local Shenzhen urban hukou.

The category earning too little for commercial market rents and too much for public housing is a well-known phenomenon from other East- and Southeast-Asian cities. In cities like Hong Kong, Singapore and Guangzhou, this unfortunate category has been described as the "sandwich class" (Ying et al. 2013; Chiu 2002; Siew Eng, Kong 1997). Some of our respondents solved their affordability problems by sharing their apartment or flat with friends, colleagues or family. This may temporarily solve the affordability problem for them, but in the longer run it is not the most desirable solution. A few quotes illustrating the affordability concerns of respondents that could probably be considered as members of the "sandwich class":

"Chinese young people can't really afford the house, they need support from parents, in China we call them 'housing slaves', we are under pressure, so it's very difficult" (Shop owner/designer, OCT-LOFT).

"The only way I can really afford it is to share it" (Architect, OCT-LOFT).

The lowest income respondents that lacked the Shenzhen local urban hukou solved their accommodation problems in other ways. Five of our respondents found a home in the urban villages as their only affordable option. Several other respondents referred 
to personnel, colleagues or friends living in urban villages. Other attraction factors of the urban villages mentioned were their location close to public transport links, close to the workplace or within reasonable travel time, and/or the lively atmosphere with lots of small companies and markets and many people on the streets.

University students and recently graduated working as interns or in other precarious contract situations often share apartments or even small rooms with fellow students or graduates. For some of them this situation may only be temporary until they will manage to realize the career they dream of; for others, this career may remain a far-fetched dream. They may be considered as a part of China's "ant tribe": high educated and high qualified young people that have to settle for sub-standard living conditions and low-paid jobs in or outside the creative industries (Gu et al. 2015).

We asked the respondents to estimate which share of their spendable household income they have to pay for rent or mortgage. 11 respondents said they paid $30 \%$ or less of their household income; in most Western societies this is considered a reasonable share which most people can afford. For 15 respondents, the share of their income spent on accommodation was higher: 14 paid $30-50 \%$ of their spendable income; 1 even more than 50\%. 9 respondents did not know or did not answer this question. However, when asked whether or not the respondents considered their home affordable, 20 respondents said yes and only 5 said no (10 respondents did not answer the question). This may imply that what is considered "affordable housing" in Western societies differs from what is considered affordable in Shenzhen or maybe also more generally in Chinese cities. Maybe this is a matter of cultural differences, or what one is used to, or different conditions on the Chinese housing market compared to Western societies. Another possibility is that our respondents are willing to pay relatively much for their housing and give less priority to other products or services.

The question what would be the maximum acceptable income share for housing seemed difficult or sensitive. 22 out of 35 respondents did not know, did not answer, or said something like "it depends on my future situation". Of the 13 people that answered this question, 8 said they wanted to pay up to $40 \%$ of their income on accommodation; 5 said it could be above $40 \%$. Some respondents may have misunderstood the question or never really thought about this before. There was also one respondent answering that his living style was not that "rational" and he did not have a maximum affordable rent in mind.

\section{Satisfaction about home and neighbourhood}

Because of the diversity of our respondents, it is hard to make any generalizing statements about to what extent the creative workers we spoke to are satisfied about their home and their neighbourhood. Features of homes that were often appreciated were: the view, especially a sea or hillside view; private outdoor spaces like balconies; and living close or well-connected to work and/or shopping facilities. Many respondents referred also to specific parts of the home they liked very much, like their kitchen or their living room, or the way they decorated their home. As could be expected in a hot and humid climate like Shenzhen's, many respondents mentioned the importance 
of good ventilation. Most often mentioned as negative aspects of their home were: too high and/or rapidly rising rents; having to rent their home instead of owning it; and/or shortcomings in building quality. Maybe the (in)famous "Shenzhen speed" of building has come at the expense of building quality especially in the less expensive parts of the housing market:

"I don't like the building quality. [...] Windows don't close properly. Doors don't open properly. [...] My house is quite old. The bathroom is not high standard. The kitchen is terrible. I have termites in my room. The wood is rotten. [...] I think it's OK since I always consider it temporarily. But for sure I would not buy this place" (Architect, OCT).

What was liked most in neighbourhoods was nearness of amenities; nearness to a park, hills or the sea; convenient locations and good transport connections. However, many people also mentioned that they appreciated their quiet surroundings. The most mentioned complaint was noise, often combined with a disliking of (too) crowded streets. This is maybe a bit surprising with Florida's description of the creative class in mind. Florida claims that creative class people appreciate lively neighbourhoods packed with people and activities "24/7"; but the people we spoke to in Shenzhen more often appreciated quiet and less crowded places than busy and hectic places! There may be a difference between native Chinese and foreign creatives in Shenzhen in this respect, though; the foreigners we spoke to seemed to fit better in Florida's creative class picture. A less surprising frequent complaint, which probably all types of people would share, was about streets and other public spaces being dirty and badly maintained. Also often mentioned was the feeling of anonymity and the lack of contact with neighbours. Especially people that came to Shenzhen from villages or smaller towns mentioned this and compared it with what they were used to in their place of origin:

"Something sad is that in Shenzhen or modern cities we lost our neighbours, everyone has their own life, people are isolated. I don't know if it's the same in another country. [...] In my hometown, 1 hour driving from Shenzhen, everyone knows each other. In Shenzhen I rarely see them and they rarely see me, because I go back home late. We just have to guess who they are" (Designer/shop owner, OCT).

Another aspect mentioned frequently was the immediate neighbouring of relatively luxury high-rises and urban villages, for varying reasons. Some did not like the urban village's messy lay-out or noise or considered it an unsafe environment, others felt uneasy about the sharp contrasts between rich and poor and would appreciate a city in which wealth and living standards would be more equally spread.

\section{Where the creatives would like to live}

Asked about their preferred place of residence in case they would move, the Nanshan District was the clear winner. In total 43 answers were given (some respondents mentioned more than one location), of which 23 answers referred to Nanshan or specific parts of it as the only preferred option, or as one of the options. Again we see the effect of the current work location here, since most of our interviews were at 
work locations in Nanshan and many respondents indicated they wanted to live close to or well connected to their work location. The current place of residence probably also influenced the preferred place to move to. A common effect known from other residential preferences research is that people have only a limited knowledge of the housing market and residential environments in a city or region; this often also limits their range of perceived choices. There might well be very attractive residential environments for them somewhere in the city that they do not think of because they never saw them. Some respondents mentioned more specific locations like OCT as a whole or OCT-LOFT in particular, near Shenzhen University, Houhai and Coastal City.

A few quotes as illustrations of the kinds of reasons given for a location preference:

"Nanshan. We have both sea and mountain here. It might be similar with Hong Kong in the future" (Painter, NH E-Cool).

"I prefer to live near to Shenzhen university, I like the cultural atmosphere there, it's beautiful" (Animation designer 3, Animation World).

"I think Futian is the best place for living. Its density is not as high as Luohu. And it's not that noisy" (Interior design graduate, OCT-LOFT).

"I prefer Nanshan or Futian. Futian is convenient for traffic and there are many parks there" (Animation designer 2, Animation World).

However, some respondents did not think of moving within Shenzhen, but seriously considered moving to another city, their place of origin and/or where their family lived (often a small town or village):

"I have no idea [...]. I may think about in some other city, in Shenzhen I don't feel like living in somewhere particularly" (Design shop assistant, OCT-LOFT).

"We won't stay in Shenzhen. The rhythm here is too fast. We might go back to my hometown doing small business" (Interior designer, OCT).

We asked our respondents to name the three most important considerations determining where they would move. Especially housing price, environment (e.g. attractive urban design, amenities close by, close to nature/parks) and the location (distance to workplace and other important sites in their daily life) were mentioned often. Traffic and transport, quietness of the neighbourhood, size, safety and the neighbourhood's population composition were also mentioned, but less often.

Our respondents included an artist couple in F518: a painter and his wife, who was giving art lessons. Their answers show a mix of preferences and wishes on the one hand, and limitations of the housing market they are faced with on the other. This illustrates a more general impression from a large part of the respondents. "Somewhere quiet near downtown" seems to be the ideal of many of them, but at the same time several respondents also realize that this is not a realistic option:

"We both like watching movies, singing karaoke, shopping. However, we want to live somewhere quiet near downtown area. If the traffic was very convenient, location would be no problem" (Wife of painter, F518). 
"In Nanshan or Futian, rent is so expensive that it is not suitable for us to move there. [...] We, creative people, we do not really need a very busy place, because we are, after all, not engaged in the entertainment industry. That's why we moved to Bao'an. [...] In fact, it does not matter for someone who engages in the art living a bit far away from city centre. Artists do not really want anyone to disturb them. We could only choose places that are affordable. [...] Quite upset. We have no choices" (Painter, F518).

\title{
How can Shenzhen become more attractive for creative workers?
}

So far Shenzhen's creative city policy is mostly about attracting and facilitating creative companies and investors, while the creative workers as well as the possible creative talents of the future seem to be neglected. The policy measures taken may already be an effective creative business policy, but this is not yet a creative city policy. A creative city policy should also be about housing for creative people. To really become an attractive city for creative workers, Shenzhen's policies for creative business should be linked to its housing policies, and these policies should especially target the lower and middle income groups with affordable housing projects.

The urban villages could play an important role in this. The Shenzhen government should think twice before demolishing urban villages. For understandable reasons, particularly the most centrally located urban villages are threatened most by demolition and/or redevelopment, but these also happen to be the most important ones for creative workers at the start of their career. For them, urban villages often are one of the few, or even the only, affordable housing opportunity near their workplace. If the centrally located urban villages (like Baishizou, mentioned in the quote below) are being redeveloped, it would be better to renovate the current buildings and/or build small-scale affordable housing complexes than to demolish entire villages and replace them with yet another luxury housing estate. A photographer working in OCT-LOFT, for example, said:

\begin{abstract}
"Creative workers is a mixed concept. The urgent group is the newcomers. One of my employees I hired recently has been working here for a month and still lives in a talent apartment in Sungang, it costs him 15 RMB per day, dozens of people live together. It's a beginning, after he reaches a more stable situation he will move to places like Baishizhou for sure. [...] I think places like Baishizhou should be kept, if the public hygiene and security can be improved there, it's not bad to live there I think".
\end{abstract}

The most frequent answer to the question "what could Shenzhen City do to improve the residential situation of creative workers?" was that the city should raise the salary of creative workers. This answer fits the typically Chinese situation where many creatives work for state-owned businesses and local government may indeed have influence on their salaries. Many respondents considered improving their work situation more important than improving their housing situation. Several respondents thought the city government could not change much in the housing market, because private developers are more powerful and influential. Others, however, expected a 
more active local government, demanding lower rents and/or land prices; more public housing and making this accessible for a larger part of the Shenzhen population; more housing subsidies; improved safety; or improved home-work transport, either through better connections and/or by providing more (affordable) homes closer to workplaces.

Most respondents do not have "typically creative" expectations or demands from the Shenzhen government. Most of the answers they gave could have been given by non-creative workers as well. Maybe most creatives are not that special at all, but "just like normal people"? This might mean there would be no need for a specific "creative housing policy", but there should rather be a "housing for all" policy.

While most respondents seemed quite satisfied with living in Shenzhen, we should also point at some less satisfied respondents that did not feel comfortable in the city. They missed a "sense of belonging" in Shenzhen and asked the city government for measures that might make people like them feel more at home in the city. These respondents may represent a larger group of people without a local urban hukou that feel neglected by the Shenzhen city government:

"I think many youngsters like me come from other places, locals are a minority. [...] Somehow, it's a big difference between reality and your dream, both visible and invisible pressure comes to you that sometimes you feel like running away. If a city has a sense of belonging, you can stand the pressure no matter how big it is. But after you stay a long time here, you still drift around, you won't feel stable" (Animation designer 4, Animation World).

\section{Concluding remarks}

Shenzhen aspires to become a creative city. Its creative city strategy so far seems mainly concerned with attracting more creative companies and jobs and facilitating the companies that are already there. However, a comprehensive creative city strategy should also address the needs of creative workers, not only at their workplaces but also in their living environment. Such links between workspace, residential space and amenities have only recently become more important in Shenzhen's urban (re) development strategies. So far only little is known about the residential preferences of Shenzhen's higher educated and skilled workers. The interview-based analysis presented in this paper can hopefully contribute to increase the attention for this topic in both academic and policy circles. Since the respondent sample is small and not representative for creative workers in Shenzhen as a whole, it is not possible to draw generalizing conclusions about the preferences and needs of Shenzhen's creative workers. Still, the results may give some first indications of possibly relevant aspects of a housing strategy for creative workers. "Creative workers" are a highly diverse group, so a "one size fits all" approach for all creatives will definitely not work; they should not be considered as a distinct "class" with its own specific lifestyle and preferences. They would probably benefit more from a housing strategy aimed at all Shenzheners in which diversity of population in terms of income, education, origin ("local" or "migrant") etc. would be taken into account. The concerns voiced specifically by 
those at the start of their career and/or with lower incomes point at the importance of providing sufficient affordable housing and easy access to it, both for locally born and raised Shenzheners and for (children of) migrants. Next to luxury "urban enclaves", there should also remain enough room for start-up milieus; a careful redevelopment of urban villages would in this respect probably be much more useful than replacing them with new housing development projects. There may also be a specific need for adequate and affordable housing for those in-between the lowest and the highest incomes (the "sandwich class"); Shenzhen currently mainly seems to have either very expensive or very cheap housing and not enough in-between.

This analysis has maybe raised more questions than it was able to answer; several avenues for further research could be considered, hopefully contributing to a Shenzhen in which creatives do not only like to work, but also like to live.

\section{References}

Bontje, M. 2014. Creative Shenzhen? A Critical View on Shenzhen's Transformation from a Low-Cost Manufacturing Hub to a Creative Megacity, International Journal of Cultural and Creative Industries 1(2): 52-67.

Bontje, M.; Musterd, S; Kovács, Z.; Murie, A. 2011. Pathways toward European Creative-Knowledge City-Regions, Urban Geography 32(1): 80-104. http://dx.doi.org/10.2747/0272-3638.32.1.80

Carpenter, J.; Lees, L. 1995. Gentrification in New York, London and Paris: An International Comparison, International Journal of Urban and Regional Research 19(2): 286-303.

http://dx.doi.org/10.1111/j.1468-2427.1995.tb00505.x

Cartier, C. 2002. Transnational Urbanism in the Reform-Era Chinese City: Landscapes from Shenzhen, Urban Studies 39(9): 1513-1532. http://dx.doi.org/10.1080/00420980220151637

Cheng, Z. 2014. The New Generation of Migrant Workers in Urban China, in Cheng, Zh.; Wang, M.; Chen, J. (Eds.). Urban China in the New Era: Market Reforms, Current State, and the Road Forward. Heidelberg, New York, Dordrecht, London: Springer, 125-154.

http://dx.doi.org/10.1007/978-3-642-54227-5_7

Chiu, R. L. H. 2002. Social Equity in Housing in the Hong Kong Special Administrative Region: A Social Sustainability Perspective, Sustainable Development 10(3): 155-162.

http://dx.doi.org/10.1002/sd.186

Clark, T. N.; Lloyd, R.; Wong, K. K; Jain, P. 2002. Amenities Drive Urban Growth, Journal of Urban Affairs 24(5): 493-515. http://dx.doi.org/10.1111/1467-9906.00134

Costa, C. 2013. The Adoption of the Global Discourse of Creativity-Led Planning and "Creative City" in Urban China: PhD Thesis. Università Iuav di Venezia. Unpublished Source.

Douglass, M.; Wissink, B.; Kempen, van R. 2012. Enclave Urbanism in China: Consequences and Interpretations, Urban Geography 33(2): 167-182. http://dx.doi.org/10.2747/0272-3638.33.2.167

Florida, R. 2002. The Rise of the Creative Class: And How It's Transforming Work, Leisure, Community and Everyday Life. New York: Basic Books.

Florida, R.; Mellander, Ch.; Qian, H. 2012. China's Development Disconnect, Environment and Planning A 44: 628-648. http://dx.doi.org/10.1068/a44284

Glaeser, E. L. 2004. Review of Richard Florida's The Rise of the Creative Class [online], [cited 15 September 2015]. Available from Internet: http://scholar.harvard.edu/files/glaeser/files/book_ review_of_richard_floridas_the_rise_of_the_creative_class.pdf 
Gu, Ch.; Kesteloot, Ch; Cook, I. G. 2015. Theorising Chinese Urbanization: A Multi-Layered Perspective, Urban Studies 52(14): 2564-2580. http://dx.doi.org/10.1177/0042098014550457

Hansen, H. K.; Niedomysl, Th. 2009. Migration of the Creative Class: Evidence from Sweden, Journal of Economic Geography 9(2): 191-206. http://dx.doi.org/10.1093/jeg/lbn046

Hao, P. 2012. Spatial Evolution of Urban Villages in Shenzhen: PhD Thesis. Utrecht University. Unpublished Source.

He, Sh. 2013. Evolving Enclave Urbanism in China and Its Socio-Spatial Implications: The Case of Guangzhou, Social and Cultural Geography 14(3): 243-275.

http://dx.doi.org/10.1080/14649365.2012.762112

He, Sh. 2010. New-Build Gentrification in Central Shanghai: Demographic Changes and Socioeconomic Implications, Population, Space and Place 16(5): 345-361.

Keane, M. 2011. China's New Creative Clusters: Governance, Human Capital and Investment. London, New York: Routledge.

Ley, D. 1996. The New Middle Class and the Remaking of the Central City. Oxford: Oxford University Press.

Liu, W.; Ng, M. K. 2009. Heritage Conservation in China's "Instant City" - Shenzhen, Planning Theory and Practice 10(2): 289-297.

Lloyd, R. 2002. Neo-Bohemia: Art and Neighborhood Redevelopment in Chicago, Journal of Urban Affairs 24(5): 517-532. http://dx.doi.org/10.1111/1467-9906.00141

Malanga, S. 2004. The Curse of the Creative Class, City Journal Winter Issue [online], [cited 11 September 2015]. Available from Internet: http://www.city-journal.org/html/curse-creative-class-12491.html

Martin-Brelot, H.; Grossetti, M.; Eckert, D.; Gritsai, O.; Kovács, Z. 2010. The Spatial Mobility of the "Creative Class": A European Perspective, International Journal of Urban and Regional Research 34(4): 854-870. http://dx.doi.org/10.1111/j.1468-2427.2010.00960.x

Miao, J. T. 2016. Housing the Knowledge Economy in China: An Examination of Housing Provision in Support of Science Parks, Urban Studies (in press).

http://dx.doi.org/10.1177/0042098015627106

Morrison, N. 2014. Building Talented Worker Housing in Shenzhen, China, to Sustain Place Competitiveness, Urban Studies 51(8): 1539-1558. http://dx.doi.org/10.1177/0042098013510955

Musterd, S.; Gritsai, O. 2013. The Creative Knowledge City in Europe: Structural Conditions and Urban Policy Strategies for Competitive Cities, European Urban and Regional Studies 20(3): 343-359. http://dx.doi.org/10.1177/0969776412439199

Ng, M. K. 2003. City Profile: Shenzhen, Cities 20(6): 429-441.

http://dx.doi.org/10.1016/j.cities.2003.08.010

O’Connor, J.; Liu, L. 2014. Shenzhen's OCT-LOFT: Creative Space in the City of Design, City, Culture and Society 5(3): 131-138. http://dx.doi.org/10.1016/j.ccs.2014.07.003

O'Connor, J.; Xin, G. 2006. A New Modernity? The Arrival of "Creative Industries" in China, International Journal of Cultural Studies 9(3): 271-283. http://dx.doi.org/10.1177/1367877906066874

Peck, J. 2005. Struggling with the Creative Class, International Journal of Urban and Regional Research 29(4): 740-770. http://dx.doi.org/10.1111/j.1468-2427.2005.00620.x

Pratt, A. C. 2008. Creative Cities: The Cultural Industries and the Creative Class, Geografiska Annaler: Series B - Human Geography 90(2): 107-117.

http://dx.doi.org/10.1111/j.1468-0467.2008.00281.x 
Scott, A. J. 2006. Creative Cities: Conceptual Issues and Policy Questions, Journal of Urban Affairs 28(1): 1-17. http://dx.doi.org/10.1111/j.0735-2166.2006.00256.x

Siew Eng, T.; Kong, L. 1997. Public Housing in Singapore: Interpreting "Quality" in the 1990s, Urban Studies 34(3): 441-452. http://dx.doi.org/10.1080/0042098976069

Song, W.; Wu, Q. 2010. Gentrification and Residential Differentiation in Nanjing, China, Chinese Geographical Science 20(6): 568-576. http://dx.doi.org/10.1007/s11769-010-0432-2

Wang, W. W.; Fan, C. C. 2012. Migrant Workers' Integration in Urban China: Experiences in Employment, Social Adaptation, and Self-Identity, Eurasian Geography and Economics 53(6): 731-749. http://dx.doi.org/10.2747/1539-7216.53.6.731

Wu, W.; Gaubatz, P. 2013. The Chinese City. London, New York: Routledge.

Wuwei, L. 2011. How Creativity Is Changing China. Keane, M. (Ed.). London, New York: Bloomsbury Academic.

Ying, Q.; Luo, D.; Chen, J. 2013. The Determinants of Homeownership Affordability among the "Sandwich Class": Empirical Findings from Guangzhou, China, Urban Studies 50(9): 18701888. http://dx.doi.org/10.1177/0042098012470398

Zacharias, J.; Tang, Yu. 2010. Restructuring and Repositioning Shenzhen, China's New Mega City, Progress in Planning 73(4): 209-249. http://dx.doi.org/10.1016/j.progress.2010.01.002

\title{
NAMIE ŠENDŽENE? KŪRYBININKŲ APSIRŪPINIMO BŪSTU GALIMYBĖS IR BŪSTUI TEIKIAMOS PIRMENYBĖS KARJERISTUQ KŪRYBINIAME MIESTE
}

\section{Marco BONTJE}

\begin{abstract}
Santrauka
Šendženas, kaip pramoninès masinès gamybos miestas, augo greitai, tačiau dabar jis transformavosi į naujovišką ir kūrybini miestą. Šendženo kūrybinių industrijų rémimo politika paprastai taikoma kompanijoms ir verslininkams. Tam, kad Šendženas iš tikrujų taptų patraukliu kūrybiniu miestu, būtina kreipti dėmesi i būstų, skirtų kūrybiškai talentingiems žmonèms, politiką. Šiame straipsnyje pateikiama interviu pagrindu atlikta kūrybininkų apsirūpinimo būstu situacijų ir gyvenamajai vietai teikiamos pirmenybės Šendžene analizè. Nors kūrybininkams, gaunantiems gerus atlyginimus, nesunku susirasti patrauklius būstus ir rajonus Šendžene, trūksta rajonų už prieinamą kainą neseniai baigusiems studijas ir pradedantiesiems kūrybininkams. Šendženo kūrybinio miesto strategijoje turètų būti atsižvelgiama ị kūrybos darbuotojų socioekonominę ivairovę.
\end{abstract}

Reikšminiai žodžiai: Kinija, kūrybinis miestas, kūrybos darbuotojai, apsirūpinimas būstu, gyvenamosios pirmenybès, Šendženas. 